\title{
HUBUNGAN MONITORING PARENTAL DAN KEBIASAAN PEER GROUP DENGAN PERILAKU MEROKOK REMAJA SLTP DI KOTA MATARAM
}

\author{
Mukminah \\ Dosen Biologi Fakultas Tarbiyah dan Keguruan (FTK) UIN Mataram \\ mien_mukminah@uinmataram.ac.id
}

\begin{abstract}
ABSTRAK
Perilaku merokok adalah aktivitas subjek yang berhubungan dengan perilaku merokoknya, yang diukur melalui intensitas merokok, tempat merokok, waktu merokok dan fungsi merokok dalam kehidupan. Merokok sudah menjadi permasalahan nasional bahkan internasional. Perokok bukan hanya berasal dari kalangan dewasa, tetapi didominasi oleh remaja dengan kisaran usia pertama kali merokok yang semakin muda. Tujuan penelitian ini adalah untuk mengetahui hubungan Monitoring parental (pengawasan orang tua) dan kebiasaan peer group (teman sebaya) dengan perilaku merokok pada remaja SLTP di Kota Mataram. Jenis penelitian ini adalah penelitian observasional dengan pendekatan crosssectional study. Hasil penelitian menunjukkan hasil yang signifikan antara variabel dependen dan independen. Hubungan monitoring parental (pengawasan orang tua) dengan perilaku merokok remaja SLTP terdapat hubungan yang signifikan dengan $p$ value $>0.05(p=0.440)$. Selanjutnya untuk variabel pengaruh teman sebaya (peer group) dengan perilaku merokok remaja menunjukkan hubungan yang signifikan dengan $p$ value $>0.05(p=0.642)$. Nilai ini menunjukkan hubungan yang sangat tinggi atau erat, lebih tinggi dari hubungan pengawasan orang tua. Upaya yang lebih tegas perlu dilakukan keluarga untuk menghindarkan remaja dari pengaruh rokok, tidak hanya memberikan informasi tentang bahaya merokok, tapi lebih kepada memberikan teguran baik berupa ucapan atau sanksi. Anggota keluarga tidak disarankan untuk merokok atau bersikap permisif terhadap perilaku merokok. Pergaulan dengan teman sebaya harus diberikan pengawasan, karena pengaruh teman sebaya terhadap perilaku merokok remaja jauh lebih tinggi atau erat dibandingkan dengan pengaruh pengawsan orang tua.
\end{abstract}

Kata Kunci : Remaja; Perilaku Merokok; Monitoring parental; Kebiasaan Peer group

\section{ASSOCIATION BETWEEN PEER AND PARENTAL CONTROL FACTORS AND SMOKING BEHAVIOR OF ADOLECENTS IN JUNIOR HIGH SCHOOL IN MATARAM}

\begin{abstract}
The purpose of this study was to determine the relationship between peer and parental control factors and smoking behaviour of adolecents among junior high school students in Mataram. Observational study was used to collect data from 108 students aged 12 to 17 on their own smoking status and parental controls. The result showed secondary students who smoke are subjected to peer group pressures and they have fewer parental controls with regard to smoking. More pressures on smoking within the peer groups were associated with a greater likelihood of smoking behaviour ( $p>0.05$; $\mathrm{p}=0.642$ ). However, parental controls on smoking have also been found to have influence to decreasing the likelihood of smoking behaviour among $7^{\text {th }}$ and $8^{\text {th }}$ students $(p>0.05 ; p=0.440)$. In general, peers has stronger effects on initiation of adolecents smoking behavior than parental control influences. This findings suggest that more extensive controls on smoking at home may reduce adolecents smoking behaviour. Thus, smoking prevention for adolecents might be focused on social context such as, resisting to peer pressure and enhacing parental communication.
\end{abstract}

Keywords: adolescent; smoking behavior; parental control; peer

\section{Pendahuluan}

Masyarakat Indonesia adalah masyarakat yang didominasi oleh kalangan produktif yakni remaja. Salah satu kebiasaan masyarakat saat ini yang hampir bisa ditemui di setiap kalangan masyarakat adalah perilaku merokok. Rokok atau perilaku merokok bukan hal baru dalam kehidupan masyarakat kita. Perokok bisa laki-laki ataupun perempuan dan dari kalangan tua maupun muda.

Perilaku merokok dilihat dari sudut pandang kesehatan maupun ekonomi sangat merugikan. Baik merugikan diri sendiri maupun untuk orang di lingkungan sekelilingnya. Dilihat dari sisi kesehatan, pengaruh bahan-bahan kimia yang 
dikandung dalam rokok seperti nikotin, Co (Carbonmonoksida) dan tar yang dapat memacu kerja susunan syaraf pusat dan susunan syaraf simpatis sehingga menyebabkan tekanan darah menigkat dan detak jantung menjadi lebih cepat (Kendal, P.C \& Hammen, C, 1998).

Penelitian Kaplan et al (1993)., merokok dapat menstimulasi kanker dan berbagai penyakit seperti penyempitan pembuluh darah, tekanan darah tinggi, penyakit jantung, paru-paru dan penyakit bronkitis kronis. Jika seorang perokok memiliki istri yang sedang hamil, bisa menyebabkan kelahiran prematur, berat badan lahir rendah (BBLR) pada bayinya, mortalitas prenatal, kemungkinan lahir dalam keadaan cacat dan mengalami gangguan dalam perkembangan.

Berdasarkan data The Asean Tobacco Control Report Card tahun 2008, sebanyak 30,1\% penduduk Asia tenggara adalah perokok. Sebanyak 57.563.866 penduduk dewasa Indonesia adalah perokok. Jumlah tersebut menjadikan Indonesia sebagai negara konsumen rokok tertinggi ke lima di dunia. Kondisi ini sangat memprihatinkan dan perlu perhatian yang serius dari pemerintah dalam upaya menekan angka perokok yang semakin bertambah baik dari kuantitas perokoknya dan dari usia perokok yang terus menuju arah yang semakin muda. Perokok bukan hanya orang dewasa tetapi didominasi oleh remaja dan mereka belajar merokok mulai dari usia remaja awal yang memiliki kisaran usia 11 tahun.

Riset Kesehatan Dasar 2010 mencatat, 58,6 juta orang Indonesia berumur 15 tahun ke atas menjadi perokok aktif. Rinciannya, pria 55,05 juta dan perempuan 3,5 juta. Pada remaja (15-19 tahun), prevalensi merokok meningkat dari 7,1\% tahun 1995 menjadi 20,3\% tahun 2010. Bila dibiarkan, Indonesia tidak akan memiliki generasi unggul di masa depan, menurut Ketua Tobacco Control Support Center (TCSC). Rokok menghambat pertumbuhan fisik dan kemampuan otak menyerap informasi.

Remaja merupakan salah satu istilah yang diberikan untuk tahap dalam perkembangan fisik dan psikologis manusia. Faktor yang harus diperhatikan dalam mendefnisikan istilah remaja (adolescence) adalah usia. Berdasarkan usia, remaja (adolescence) diartikan sebagai masa perkembangan transisi antara masa anak-anak dan masa dewasa yang meliputi perubahan biolgis kognitif dan sosial-emosional. Sedangkan pemuda (youth) adalah istilah yang diberikan Kenniston untuk masa transisi antara remaja dan dewasa yang merupakan waktu ketergantungan ekonomi dan pribadi. Masa transisi ini bisa terjadi selama 2 sampai 8 tahun bahkan dapat sampai 1 dekade dalam masa kehidupannya (Santrock, 2003).

Menurut Peter B.A \& Elizabeth O.A, (2006), masa remaja adalah suatu proses bertahap dan setiap tahap memiliki perkembangan berbeda. Tahap pertama adalah remaja awal (early adolescent) dengan periode usia 11-14 tahun. Tahap kedua adalah remaja pertagahan (middle adolescent) denga periode usia antara 15-18 tahun dan tahap ketiga (late adolescent) adalah remaja akhir dengan periode usia antara 18-21 tahun. Penelitian ini dilakukan dengan tujuan untuk mengetahui hubungan monitoring parental (pengawasan orang tua ) dan kebiasaan peer group (teman sebaya) dengan perilaku merokok pada remaja SLTP di Kota Mataram.

\section{Bahan dan Metode}

Jenis penelitian ini adalah penelitian observasional dengan pendekatan cross-sectional study yaitu peneliti hanya melakukan observasi dan pengukuran variabel pada satu saat tertentu saja. Total populasi penelitian ini adalah semua remaja laki-laki yang masih berstatus siswa sekolah menengah pertama (SLTP) di Kota Mataram. Populasi penelitian diambil di setiap sekolah yang sudah diacak dan mewakili keadaan remaja di Kota Mataram.

Berdasarkan perhitungan besar sampel, maka jumlah sampel untuk penelitian ini adalah 97 orang siswa (n=97). Untuk mengantisipasi terjadinya missing data, maka sampel ditambah $10 \%$ menjadi 108 siswa. Sampel dalam penelitian ini diambil dengan teknik purposive sampling/judgmental sampling terhadap remaja SLTP di Kota Mataram. Pada purposive sampling dilakukan atas pertimbangan/tujuan tertentu seperti biaya, waktu maupun tenaga. Dalam pengambilan subjek penelitian di sekolah, dilakukan dengan teknik cluster random sampling sehingga yang akan menjadi subjek penelitian adalah seluruh siswa yang memenuhi kriteria inklusi dan bersedia menjadi responden. Penelitian dilakukan pada hari sabtu selama bulan Juli-Agustus. Data penelitian diperoleh dengan menggunakan kuesioner.

\section{Hasil Dan Pembahasan}

Remaja merupakan masa transisi dan masa pencarian jati diri seseorang. Dalam kurun waktu ini, semua aspek yang menunjang sangat dibutuhkan oleh seorang remaja. Aspek penunjang yang harus didapatkan antara lain, keharmonisan keluarga, monitoring yang baik dari orang tua, pergaulan yang baik dengan teman sebaya serta media massa yang dapat diakses oleh remaja. Jika ada ketimpangan dari beberapa faktor/aspek pendukung di atas, misalnya kehadiran orang tua, maka biasanya remaja akan mengalihkan dengan mendapatkan masukan dari teman sebaya.

Merokok adalah tindakan menyulut rokok dengan api kemudian menghisap batang rokok tersebut dan menghembuskan asapnya. Merokok sudah menjadi permasalahan nasional bahkan 
internasional (Dian K. \& Avin F.H, 2000). Menurut ketua Komisi Nasional Pengendalian Tembakau, Indonesia merupakan negara perokok terbesar di lingkungan negara-negara ASEAN. Hal ini berdasarkan data dari The ASEAN Tobacco Report Tahun 2007, yang menyebutkan bahwa jumlah perokok di ASEAN mencapai 124.691 juta orang. Indonesia merupakan negara dengan peringkat pertama dengan jumlah perokok 57.563 juta orang atau sekitar 46,16\% dari total perokok di negaranegara ASEAN. Lebih mencengangkan lagi menurut data WHO (World Health Organization) pada tahun 2008, menetapkan Indonesia sebagai negara terbesar ketiga pengguna rokok. Lebih dari 60 juta penduduk Indonesia mengalami ketidakberdayaan akibat dari adiksi nikotin rokok, dan kematian akibat mengkonsumsi rokok tercatat lebih dari 400 ribu orang per-tahun.

Salah satu kondisi yang menjadi permasalahan di kalangan remaja adalah perilaku merokok. Gejala merokok di kalangan remaja salah satu penyebabnya adalah rasa ingin tahu atau ingin mencoba hal baru. Selain karena faktor tersebut, pengaruh pergaulan dan keinginan untuk diterima dalam komunitas remajanya juga menjadi hal yang tidak kalah berpengaruh. Faktor-faktor ini menjadi pencetus perilaku merokok di kalangan remaja.

Jumlah sampel dalam penelitian adalah 108 siswa SLTP yang terbagi menjadi 43\% (46 siswa) berasal dari SMP dan 57\% (62 siswa) berasal dari MTs. Data jumlah sampel dapat dilihat pada gambar di bawah ini.

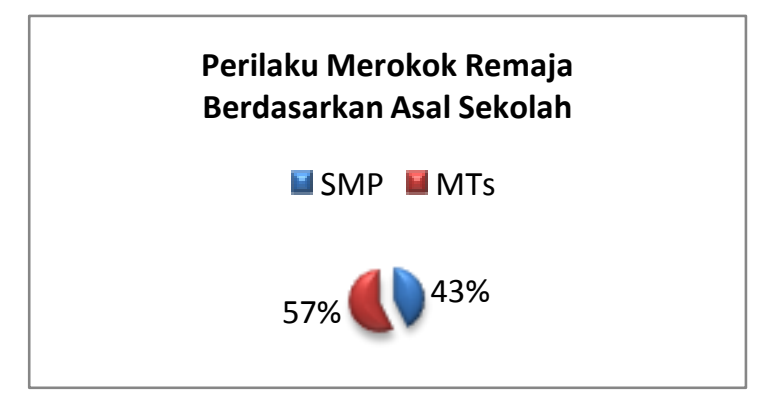

Gambar 1. Persentase responden berdasarkan asal sekolah

Berdasarkan gambar di atas responden dalam penelitian ini lebih banyak berasal dari Madrasah Tsanawiyah (MTs). Selanjutnya untuk karakteristik responden berdasarkan umur didapatkan persentase usia dengan dua kategori yakni $\leq 14$ tahun berjumlah 29 siswa (27\%) dan > 14 tahun berjumlah 79 siswa (73\%). Data persentase ini dapat dilihat pada gambar di bawah ini.

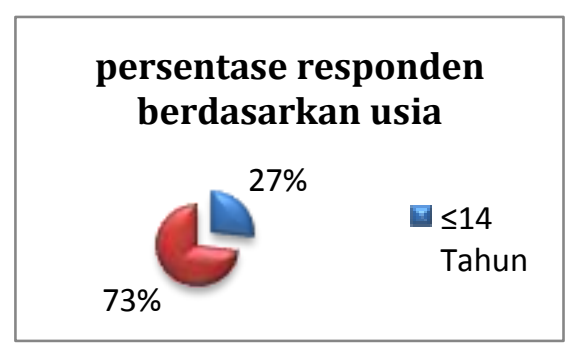

Gambar 2. Persentase jumlah responden berdasarkan usia

Responden diambil dari kelas VII, VIII dan IX, untuk masing-masing kelas, jumlah responden yang didapatkan juga berbeda-beda. Berikut data jumlah responden penelitian berdasarkan kelas responden.

\section{persentase jumlah responden berdasarkan kelas}

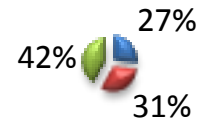

Kelas VII

Kelas VIII

Gambar 3. Persentase jumlah responden berdasarkan kelas di sekolah

Berdasarkan hasil analisis data diperoleh hasil yang signifikan antara variabel dependen dan independen. Hubungan Monitoring orang tua dengan perilaku merokok remaja SLTP terdapat hubungan yang signifikan dengan $p$ value $>0,05$ ( $p$ $=0,440$ ). Hasil pengujian menunjukkan bahwa terdapat hubungan yang sangat kuat antara monitoring atau pengawasan orang tua dengan perilaku merokok anak. Orang tua yang melakukan pengawasan yang ketat terhadap anak dan tidak bersikap permisif terhadap rokok/perilaku merokok, memperlihatkan bahwa rata-rata anak tidak akan berperilaku merokok. Terlihat pula bahwa anak yang merokok biasanya berasal dari keluarga yang orang tua (ayah) merokok, alasan yang sering dikemukakan oleh anak adalah mereka mempunyai orang tua (panutan) yang juga merokok. Nururahman, mengungkapkan hal senada dalam prosiding seminar nasionalnya. Kebiasaan merokok dapat disebabkan karena beberapa pengaruh antara lain: 1) pengaruh orang tua, dimana salah satu temuan tentang remaja perokok adalah bahwa anak muda yang berasal dari rumah tangga yang tidak bahagia, dimana orang tua tidak begitu memperhatikan anakanaknya dan memberikan hukuman fisik yang keras, akan lebih mudah untuk menjadi perokok dibandingkan anak-anak muda yang berasal dari lingkungan rumah tangga yang bahagia karena 
rokok dianggap mampu menghilangkan persoalan yang mereka hadapi. Selain itu kebiasaan orang tua merokok dalam lingkungan rumah juga dapat menjadi contoh langsung bagi anak-anak untuk mengikuti pola hidup orang tua mereka. 2) pengaruh teman, di mana lingkungan pergaulan remaja akan memberi pengaruh yang sangat besar terhadap sikap dan perilaku remaja. 3) faktor kepribadian, dimana orang mencoba untuk merokok karena alasan ingin tahu, ingin melepaskan diri dari rasa sakit, ingin membebaskan diri dari kebosanan, atau ingin dianggap sebagai pria dewasa. 4) pengaruh iklan, dimana iklan-iklan di media massa dan elektronik menampilkan gambaran dengan sangat jelas bahwa perokok adalah lambang kejantanan dan glamor, membuat remaja sering kali terpicu untuk mengikuti perilaku dalam iklan tersebut. Hasil penelitian ini senada dengan penelitian Hidayaningsih dkk ( 2010), periaku merokok dipengaruhi oleh beberapa faktor, penelitian dilakukan di Makassar menunjukkan bahwa tingkat pendidikan dan pengawasan orang tua merupakan beberapa faktor yang dianggap memiliki hubungan yang signifikan dengan perilaku berisiko remaja termasuk perilaku merokok. Bedanya dengan penelitian ini, peneliti tidak memasukkan variabel pendidikan orang tua, hanya pengawasan orang tua saja, tapi memiliki hasil yang sama yakni memperlihatkan adanya hubungan antara perilaku merokok remaja dengan pengawasan orang tua. Sugiarto (2006), menambahkan bahwa faktor keluarga memberikan kontribusi besar terhadap perilaku anak jalanan, baik yang positif maupun negatif.

Keluarga berperan strategis membentuk sikap remaja. Keluarga merupakan sekolah dan tempat pembelajaran pertama bagi remaja. Orang tua merupakan teladan bagi anak-anak mereka, interaksi yang mendalam antara orang tua dan anak akan melahirkan karakter yang mirip diantara mereka. Transmisi vertikal perilaku dilakukan oleh orang tua berupa sikap permisif orang tua terhadap perilaku merokok. Orang tua atau saudara yang merokok merupakan agen imitasi yang baik bagi remaja. Jika keluarga tidak merokok, maka sikap permisif orang tua merupakan pengukuh positif atas perilaku merokok. Di beberapa penelitian lain, orang tua merokok dianggap sebagai legitimasi merokok bagi anak-anak mereka.

Variabel pengaruh teman sebaya (peer group) dengan perilaku merokok remaja menunjukkan hubungan yang signifikan dengan $p$ value $>0,05(p$ $=0,642$ ). Nilai ini menunjukkan hubungan yang sangat tinggi, lebih tinggi dari hubungan pengawasan orang tua. Keadaan ini sangat mungkin terjadi, karena masa remaja adalah masa pencarian jati diri dan ingin diakui oleh komunitas maupun lingkungannya. Remaja lebih setuju dengan berbagai persepsi dalam gengnya dari pada apa yang dijelaskan orang tua atau keluarganya. Oktavia (2010) menyebutkan bahwa teman sebaya memegang peran yang sangat berarti bagi remaja, karena remaja lebih sering menghabiskan waktu bersama teman sebayanya. Dalam penelitian Oktavia mendapati $87 \%$ remaja yang memiliki kebiasaan merokok, mempunyai sekurangkurangnya satu atau lebih teman yang juga perokok.

Pengaruh kelompok sebaya dengan perilaku berisiko pada remaja dapat terjadi melalui mekanisme peer sosialization, dengan arah pengaruh berasal dari kelompok sebaya yang artinya ketika remaja bergabung dengan kelompok sebayanya, maka seorang remaja akan dituntut untuk berperilaku sama dengan kelompoknya, sesuai dengan norma yang berkembang dalam kelompoknya.

Pengaruh teman sebaya terhadap perilaku merokok sangat besar yang terbukti bahwa 54\% siswa pernah ditawari merokok oleh teman. Teman sebaya secara positif mempengaruhi niat remaja merokok dan menjadi faktor paling dominan. Kelompok sebaya merupakan sumber penting dari rokok pertama remaja. Merujuk konsep transmisi perilaku, pada dasarnya perilaku dapat ditransmisikan melalui transmisi vertikal dan horizontal. Transmisi horizontal dilakukan oleh teman sebaya. Kebutuhan untuk diterima sering kali membuat remaja berbuat apa saja agar dapat diterima oleh kelompoknya dan terbebas dari sebutan "pengecut" atau "banci".

Menurut Kurt Lewin dalam Komalasari dan Helmi (2008), kebiasaan merokok selain dipengaruhi oleh faktor dari dalam diri seseorang, juga dipengaruhi oleh faktor lingkungan. Faktor dari dalam diri remaja dapat dilihat dari kajian perkembangan remaja. Dikatakan oleh Erikson ( Gatchel, 1989), hal tersebut berkaitan dengan adanya krisis aspek psikososial yang dialami pada masa perkembangannya yaitu masa ketika mereka mencari jati diri. Pada masa ini sering dilukiskan sebagai masa badai dan topan karena ketidaksesuaian antara perkembangan fisik yang sudah matang dengan perkembangan psikis dan sosial yang belum matang. Upaya-upaya untuk menemukan jati diri tersebut tidak semua dapat berjalan sesuai harapan masyarakat. Beberapa remaja melakukan perilaku merokok sebagai cara kompensatoris, sebagaimana yang dikatakan oleh Brigham (1991) dalam Komalasari dan Helmi (2008) bahwa perilaku merokok merupakan perilaku simbolisasi dari kematangan, kekuatan, kepemimpinan, dan daya tarik lawan jenis. Seperti yang disampaikan oleh Daravil dan Powell (2002) bahwa remaja cenderung merokok, karena memiliki teman-teman atau keluarga yang juga 
merokok. Demikian juga dengan hasil penelitian yang dilakukan Trucco et al.,(2011), di New York, kelompok teman sebaya diakui dapat mempengaruhi pertimbangan dan keputusan remaja tentang perilakunya. Adanya peran dan persetujuan teman sebaya dengan niat merokok dan konsumsi alkohol ke depannya akan membuat remaja melegalkan perilaku tersebut.

Penelitian yang dilakukan oleh Cahyo K, menemukan bahwa umur mulai merokok pertama kali yakni 7-15 tahun, hal tersebut memperlihatkan bahwa anak-anak sudah mengenal rokok sejak bangku SLTP bahkan sejak kelas 2 Sekolah Dasar. Siswa yang mulai merokok pada umur 12 tahun atau lebih muda, lebih cenderung menjadi perokok berat dan merokok secara teratur, daripada siswa yang mulai merokok pada usia yang lebih tua. Hal ini senada juga berdasarkan hasil survei LM3 (1998) menyebutkan bahwa $58 \%$ anak pria usia 10 tahun ke atas telah menjadi perokok minimal 1 batang sehari selama tiga bulan. Semakin awal umur seseorang untuk merokok maka semakin banyak rokok yang dihisapnya sehingga semakin tinggi pula risiko untuk mendapatkan penyakit.

Apabila dilihat dari LOV (List of value), dunia remaja termasuk dalam segmen individualis dengan menganut nilai-nilai seperti bersenangsenang, berprestasi dan mengatur diri sendiri. Bersenang-senang berhubungan langsung dengan kenikmatan atau penghargaan secara fisik, serta mengharapkan hidup yang menyenangkan, kebahagiaan dan keceriaan. Remaja merasa bisa mengatur diri sendiri, yang ditunjukkan dengan cara berusaha untuk menjadi seseorang yang dapat diandalkan dan tergantung pada diri sendiri dalam memutuskan sesuatu.

Selanjutnya persepsi remaja terhadap perilaku merokok, diungkapkan oleh Rodenstock bahwa perilaku individu ditentukan oleh motif dan kepercayaannya tanpa memperdulikan apakah motif dan kepercayaan itu sesuai atau tidak dengan pandangan orang lain tentang apa yang baik untuk individu tersebut. Salah satunya adalah tentang ancaman penyakit yang bersangkutan, dalam hal ini termasuk kegawatan dan kerentanan terkena penyakit tersebut. Persepsi terhadap kegawatan penyakit akibat rokok diakui oleh sebagian besar remaja yang ditunjukkan dengan perasaan takut akan penyakit tersebut setelah melihat contoh, gambar-gambar atau bahkan sampai merasakan sendiri. Meskipun demikian hanya sebagian kecil yang kemudian merasa rentan akan terkena penyakitnya.

Risiko terkena penyakit akibat rokok diakui oleh sebagian kecil remaja yang menjadi subjek penelitian, sementara sebagian kecil yang lain merasakan tidak adanya risiko dari perilaku merokok mereka, karena tidak ada kejadian nyata yang dapat membuat mereka percaya bahwa penyakit-penyakit yang disebabkan oleh rokok tersebut benar adanya dan tidak hanya sebatas iklan. Beberapa subjek penelitian justru kurang menghiraukan risiko terkena penyakit akibat rokok, selama dia mendapatkan maanfaat dari rokok tersebut yakni menghilangkan rasa stres. Dengan beberapa keyakinan tersebut, subyek tetap memutuskan untuk merokok. Hal ini sesuai dengan teori Green yang menyatakan bahwa keyakinan merupakan salah satu faktor yang memperkuat seseorang untuk melakukan sesuatu.

Hasil riset Lembaga Menanggulangi Masalah Rokok (Republika, 1998), menyebutkan bahwa anak-anak di Indonesia sudah ada yang mulai merokok pada usia 9 tahun. Smet (1994) dalam Komalasari dan Helmi (2008), mengatakan bahwa usia pertama kali merokok umumnya berkisar antara usia 11-13 tahun dan umumnya remaja merokok sebelum usia 18 tahun. di Amerika Serikat hampir 50\% perokok merupakan usia remaja (Theodorus, 1994). Jika menilik data-data di atas, dapat dikatakan bahwa perilaku merokok sudah dimulai pada saat anak-anak dan remaja. Hampir sebagian besar remaja mengetahui dan memahami akibat buruk dari asap rokok, tetapi mereka masih saja melakukan perilaku merokok tersebut.

\section{Kesimpulan}

Merokok adalah suatu perilaku yang dipelajari, pembelajaran mengenai perilaku merokok biasanya didapatkan remaja dari lingkungan keluarga (secara vertikal) dan bisa juga dari lingkungan teman sebaya (secara horizontal). Pengawasan orang tua (monitoring parental) mempengaruhi perilaku merokok remaja SLTP di Kota Mataram. Anak yang mendapatkan pengawasan yang ketat dari orang tuanya, biasanya tidak berperilaku merokok. Demikian sebaliknya, orang tua atau keluarga yang bersikap permisif terhadap rokok atau perilaku merokok, akan melahirkan anak-anak yang merokok dan bersikap permisif terhadap rokok. Pengaruh teman sebaya menunjukkan hasil yang signifikan, dimana sebagian besar kasus merokok pada remaja, diawali dengan adanya pengaruh atau dorongan dari teman sepermainan atau yang biasa disebut dengan istilah "geng". Hal ini karena remaja ingin diterima di dalam komunitasnya, sehingga semaksimal mungkin mereka akan meniru atau melakukan hal yang menjadi kebiasaan di dalam komunitas tersebut.

\section{Daftar Pustaka}

Ahyati, M. dan Duarsa, A.B.S., (2013). Hubungan Merokok Dengan Kejadian ISPA pada Mahasiswa Politeknik Kesehatan 
Kementrian Kesehatan Tanjung Karang. Jurnal Kesehatan Masyarakat, 7(2), 4753.

Azwar, S., (2011). Metode Penelitan. Yogyakarta: Pustaka Pelajar.

Cahyo, K., Wigati, P. A., Shaluhiyah, Z., (2012). Rokok, Pola Pemasaran dan Perilaku Merokok Siswa SMA/ Sederajat di Kota Semarang. Media Kesehatan Masyarakat Indonesia, 11(1): 75-84.

Departemen Kesehatan RI. (2004). Perokok Pasif Mempunyai Risiko Lebih Besar Dibanding Perokok Aktif, Direktorat Jendral Kesehatan Masyarakat, Direktorat Promosi Kesehatan.

Davidson, G.C \& Neale, J.M. (1990). Abnormal Psychology, New York: John Willey \& Sons.

Daravill W. \& Powell K. (2002). The Puberty Book, Jakarta: Gramedia.

Gatchel, R.J. (1989). An Introduction to Health Psychology, New York; Mc Graw -Hill Book Company.

Hendra, S.B., \& Kurniajati, S. (2013). Peran Orang Tua Dalam Mencegah Perilaku Merokok Dengan Perilaku Merokok pada Remaja Putra (parent's role to prevent smoking behavior and smoking behavior to male adolescence), Vol.(1), 1-11.

Hidayaningsih, P.S., (2011). Faktor-faktor yang berhubungan dengan Perilaku Berisiko Remaja di Kota Makassar Tahun 2009. Jur. Bul. Penelit. Kesehat. 39 (2): 88-98

Kasali, R. (1998). Membidik Pasar Indonesia: Segmentasi, Tragetting dan Positioning, Jakarta , Gramedia Pustaka Utama.

Kaplan . (1993). Health and Human Behavior, New York: McGraw-Hill Book Co

Kementerian Kesehatan https://hellosehat.com/pusatkesehatan/berhenti-merokok/bahayamerokok-sejak-kecil-anak-remaja/. Diakses 15 Agustus 2017.

Kendal, P.C \& Hammen, C., (1998). Abnormal Psychology: Understanding Human Problems, New York:Houghton Mifflin Company.

Komasari, D., \& Helmi, A.F., (2000). Faktor-faktor Penyebab Perilaku Merokok pada Remaja. Jurnal Psikologi, No.(1); 37-47.

Nururrahmah, (2014). Pengaruh Rokok Terhadap Kesehatan dan Pembentukan Karakter Manusia, Prosiding Seminar Nasional, 1(1):78-214.

Oktavia D, (2010). Faktor Internal dan Ekternal yang Berhubungan Dengan Tindakan Merokok Siswa Laki-Laki di SMA Negeri Kota Padang Tahun 2010, Psikm Unand.
Sugiarto, Sri Tjahjorini, (2006). Faktor-faktor yang Mempengaruhi Perilaku Anak Jalanan di Bandung, Bogor dan Jakarta. Pusdiklak Kesejateraan Sosial Departemen Sosial.

Peter B.A \& Elizabeth O.A, (2006). Parental Influence on Adolescents Sexual Behaviour in Ibadan North Local Goverment Area of Oyo State, Nigeria. International Journal of African \& African American Studies, Vol.5 (1): 4155.

Prevalensi kebiasaan merokok http://www.riskesdas. litbang.depkes.go.id/2010. Diakses 20 Agustus 2017.

Rachmat, Muhammad dkk, (2013) Perilaku Merokok Remaja Sekolah Menengah Pertama: Smoking Behavior at Junior High School," Kesmas, Jurnal Kesehatan masyarakat, vol. 7 (11):502-508.

Rahmadi, A., Lestari Y., Yenita. (2013). Hubungan Pengetahuan dan Sikap Terhadap Rokok Dengan Kebiasaan Merokok Siswa SMP di Kota Padang. Jurnal kesehatan andalas, 2(1), 25-28.

Santrock. (2003). Adolescence Perkembangan Remaja, Jakarta: Erlangga.

Saryono. (2011). Metodologi Penelitian Kesehatan. Yogyakarta: Mitra Cendikia Press.

Sarwono,S W., (2011). Psikologi Remaja. Jakarta: Rajawali pers.

Satroasmoro, S., \& Ismael, S., (2011). Dasar-dasar Metodologi Penelitian Klinis (ed.4). Jakarta:Sagung Seto.

Theodorus, (1994). Ciri Perokok di Kalangan Mahasiswa/Mahasiswi Universitas Sriwijaya, Jurnal JEN. (3): 19-24.

RI, Trucco, Elisa M. (2011). Interpersona Goals and Susceptibility to Peter Influence: Risk Factor for Intentions to Initiate Subtance Use During Eary Adolescence, Jurnal Early Adolesc 31 (4): 526-547.

Uswatun H., Arina \& Sulastri. (2011). Hubungan Antara Dukungan Orang Tua, Teman Sebaya dan Iklan Rokok dengan Perilaku Merokok pada Siswa Laki-laki Madrasah Aliyah Negeri 2 Boyolali, Gaster, Vol.8 (1), 695-705. 